\title{
4 Language Development, Discourse, and Politics
}

\section{Family Language Policy Foundations and Current Directions}

\author{
Kendall A. King and Xiao Lan \\ Curdt-Christiansen
}

\section{Introduction}

This chapter presents three recent research projects in the area of family language policy (FLP) and highlights how Elizabeth Lanza's research has been foundational in the development of each. We organize our chapter around what we conceptualize as three strands of FLP work, each of which was largely defined or shaped by Lanza's ground-breaking scholarship. Early work is exemplified by Lanza's classic and highly influential research ([1997] 2004) which examined language contact and development within Norwegian-English bilingual families. This first strand of research used close discourse analysis of everyday family life to reveal what we now consider implicit FLPs and to unpack language development and use among young children. This approach and the insights from this research are still evident in recent works, as illustrated by close examination of language practices and language socialization in Malay and Chinese homes in Singapore (Curdt-Christiansen 2013a, 2013b, 2016a, 2016b). That project is presented and described here.

A second strand, evident in more recent research and framed explicitly under the banner of "family language policy" (e.g., Lanza and Li Wei 2016; Lanza and Curdt-Christiansen 2018; Curdt-Christiansen and Lanza 2018; King and Lanza 2018; Lanza 2020a) includes detailed discourse analysis of identity, ideology, and agency in understanding home language practices. This work is characterized by the use of an anthropological and ethnographic lens, as shown in multiple current projects, including Chinese families in the UK (e.g., Curdt-Christiansen and LaMorgia 2018; CurdtChristiansen 2020), one of which is detailed here.

A third and final strand of FLP takes up the political dimensions of FLP, including how nationalistic or anti-immigrant discourses impact family language decisions as well as how such decisions within families are in fact political ones. Work in this strand is evident in Lanza's examination of media and immigrant families in Norway (Purkarthofer, Lanza, and Finstad 
Berg, forthcoming) as well as current work, reviewed here, which analyses how Latino families understand restrictive immigration and deportation policies in the US (King and Fluegel, in press). Taken together, this chapter provides an overview of the development of the field of FLP with a focus on Lanza's important contributions, while simultaneously showcasing new empirical research in each of these three strands.

\section{Implicit Language Policies Within Families (Strand One)}

Lanza's early research focused on language practices and implicit policies within families. In her highly influential research of bilingual Norwegian and American families, Lanza ([1997] 2004) demonstrated how caregivers used discourse strategies to socialize children into particular language practices that resulted in divergent pathways for language development. She identified five types of discourse strategies that parents use in response to children's non-target language use: minimal grasp, expressed guess, repetition, move-on, and code-switch. In parent-child interactions, when using the minimal grasp strategy, adults pretend not to understand the language chosen by the child; the expressed guess strategy is used by adults when posing yes/no questions in the target language and accepting simple confirmation as an answer; the repetition strategy entails that adults repeat children's utterances in the target language; the move-on strategy is employed by adults when indicating comprehension and acceptance of children's (non-target) language choice, so that a conversation continues without any implicit and explicit disruptions; and with code-switch, adults either switch over completely to the other language or use an intra-sentential change of language. Lanza argued that these strategies can be placed on a continuum "indicating their potential for making a bid for a monolingual or bilingual context once the child has opened negotiations for a bilingual context through mixing" $(2007,56)$.

Lanza's early work, while not framed explicitly as FLP research, provided theoretical and analytical frameworks for researchers to conduct systematic studies of language use, development, and socialization among families in varied contexts (King, Fogle, and Logan-Terry 2008). Gafaranga (2010), for example, studied members of the Rwandan community in Belgium in which a language shift from Kinyarwanda-French bilingualism to French monolingualism was taking place. He employed Lanza's discourse strategies to analyze interactions between children and adults in the community and identified a "medium request" strategy used by youths to "talk language shift into being" (2010, 241). In a similar vein, Smith-Christmas's studies $(2016,2018)$ of an English-Gaelic speaking family on the Isle of Skye (UK) demonstrated the varied discourse strategies that were used by family members in their negotiations of which language to use in their daily routines and the implications of 
those patterns for language development. Lomeu Gomes (2020) also used the analytical framework to examine the language practices and ideologies of a Brazilian-Norwegian family in Norway. This framework of close analysis of discourse strategies allows researchers to uncover how small, everyday interactional moves result in particular language competencies, often favoring the dominant language.

Taking up these same tools, Curdt-Christiansen (2013a) studied three Chinese-English-speaking families in Singapore; she found that the mothers used different strategies when helping their children with homework. Based on her analysis of the bilingual interactions between the mothers and their children, she argued that depending on the situation and norms of code-switching acceptance in the community, mothers tended to use discourse strategies ranging from conscious requests to unconscious accommodation. She found that the discourse strategy employed is closely related to the types of FLP used in these families. For instance, the mother in the family with highly organized FLP tended to use more Chinese and less English when providing input on the development of ideas; she did so by using decontextualized academic vocabularies in Chinese despite the fact that the homework was in English. In the family with relatively unreflective FLP, the mother tended to use the "move-on" strategy and unconsciously used English when asking for clarification. The third type of identified FLP was a laissez-faire policy; in that family, the mother seemed to pay little attention to her child's dominant use of the English language when doing his Chinese homework. While all three families desired "balanced" bilingual outcomes for their children, their discourse strategies did not align with their conscious efforts with respect to stated FLPs.

In what follows, we demonstrate how Lanza's framework remains relevant and productive in multilingual families in relation to FLP in the context of Singapore, where both English and varied mother tongues are used simultaneously in different domains. These linguistic practices are the result of a forceful top-down government language policy, which recognizes four official languages: English, Mandarin, Malay, and Tamil. These official languages are, however, not equally valued. While English enjoys a high prestige because it is the language of law, business, and public affairs as well as the medium of instruction in all schools across all subjects at all levels, the remaining three official languages are designated as mother tongues, which are recognized as repositories of culture and identity related to the country's three major ethnic groups - Chinese, Malay, and Indian (CurdtChristiansen 2016a).

The (unpublished) data shared here are drawn from a larger project (2007-2010) that explored language socialization in Singaporean families by examining social interactions in multilingual families of the three major ethnic groups. The project focused on how children (ages 3-7) acquire sociocultural beliefs and knowledge through participation in language-mediated 
interactions. Data from 18 families were collected over a two-year period through ethnographic observations and interviews. Regular visits (once every three or four weeks) were conducted, and 10-15 recorded interactions (5-30 minutes) were collected from each family. Here, we present data from two Malay and two Chinese families to show how individuals in these families make sense of the different languages they use in their everyday life.

Excerpt 1 is taken from the Zakri family, which consisted of Adena

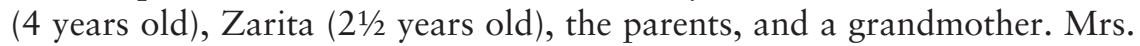
Zakri is an accountant of a large firm and Mr. Zakri a manager of the same firm. Because of their busy professional life, Adena and her little sister stay at the grandmother's house during the week and return to their parents' house on weekends. This shared child-rearing practice is widely accepted in Singapore. Adena's parents speak mostly English to her, and her grandmother speaks both English and Malay (Bahasa Melayu) to her.

Excerpt 1 is a dialogue between Adena and her grandmother on their way home from school. They are talking about the food Adena had in school.

Excerpt 1: What did you have for lunch? (October 5, 2009)

(Grandma: G; Adena: A; //-//: simultaneous utterance; bold type: codeswitching; English translation below the Malay original)

$1 \mathrm{G}: \quad$ Tengah hari makan apa?

What did you have for lunch?

2 A: //Maken..//

//Ate..//

$3 \mathrm{G}: \quad \mathrm{Nasi} / \mathrm{ke}$ ?

Ricel/?

4 A: Nasi//Nasi (nods her head)

Ricel/Rice.

5 G: Nasi dengan apa?

Rice with what?

6 A: Nasi. Dengan chicken

Rice with chicken

$7 \mathrm{G}$ : Kengtang?

Potatoes?

8 A: And kengtang.

And potatoes.

9 G: Then Lagi?

Then what else? 
10 A: Lagi ... soup

Some more soup.

$11 \mathrm{G}$ : Soup? Apa dia letak dalam soup dia?

Soup? What did she put in the soup?

$12 \mathrm{~A}$ : Chin chai [vegetable in Chinese]

Chin chai

13 G: Huh? Chin Chai? Apa chin chai?

Hub? Chin Chai? What is Chin Chai?

$14 \mathrm{~A}$ : Chin chai is a vegetable ... It's from Chinese

15 G: Bukan chin chai. Chye sim.

Not Chin Chai. Chye sim

$16 \mathrm{~A}$ : This one is Chinese.

$17 \mathrm{G}$ : Cina punya sayur, chye sim!

A Chinese vegetable, chye sim!

$18 \mathrm{~A}$ : Chin chai [insists on using Chinese]

19 G: Bukan chin chai, CHYE SIM. Abih sedap tak nasi dia?

Not Chin Chai, CHYE SIM. So, was the rice delicious?

In this series of questions and answers, the grandmother used several strategies, including move-on, adult repetition, and code-switches. For instance, in line 6, when Adena answered: "Nasi. Dengan chicken" (rice with chicken) to the question "Nasi dengan apa?" (rice with what?), the grandmother used a move-on strategy to continue with the dialogue. Consequently, the conversation carried on with Adena using both English and Malay in her utterances (L8) despite her grandmother's consistent use of Malay. In line 9, Grandma seemed to follow the cue by Adena; she also added an English conjunction then in her utterance "Then Lagi?" This move is another type of move-on strategy in which adults accept children's language behavior and carry on with the conversation (L9 and L11). The conversation then shifted to metalinguistic talk of what Chin Chia is in L13. Interestingly, in lines 14-17, Grandma used Malay to request a clarification about Chin Chia when Adena responded to the request in English. This move represents the minimal grasp strategy. However, Adena refused to repeat the utterance in Malay. Despite her intention to correct Adena in line 9, "Bukan chin chai, CHYE SIM" (Not Chin Chai, CHYE SIM), grandmother chose to desist by using a move-on strategy to continue the communication undisrupted by asking "Abih sedap tak nasi dia?" (So was the rice delicious?). The interactional moves between Grandma and Adena show not only the implicit discourse strategies for negotiation of language 
choice, but also the subtle influence of macro language policy on family language practices.

Excerpt 2 consists of a dialogue from the Yahaya family. Mrs. Yahaya is a school teacher and her husband a lawyer. Ali (4 years old) goes to a daycare during the week. The parents speak English and Malay. Although, like all parents in the study, they want Ali to become a "balanced" bilingual speaker, they tend to correct Ali when he uses Malay, as illustrated in the dialogue between Ali and his mother. In the short excerpt, Ali talks about seeing a bird in the schoolyard.

Excerpt 2: Kejar a bird (April 4, 2008) (Mrs. Y: M; Ali: A)

$1 \mathrm{M}$ : What did you do to the bird?

2 A: I kejar him. I chase him.

$3 \mathrm{M}$ : What did you do?

4 A: I chase him.

In this conversation, Ali inserted kejar (chase) into his English rejoinder to his mum's question. The mother was not particularly happy with the answer; she used a minimal grasp strategy through a direct request asking Ali to self-correct his utterance. The implicit socialization practice has a clear ideological overtone, directly related to the government's language policy in which English is given space to develop in both public and home domains.

Similar discourse strategies have also been observed in Singaporean Chinese families when parents intend to develop their children's Chinese language. Excerpt 3 is a typical example from the Goh family, which consisted of Mr. Goh (businessman), Mrs. Goh (housewife), Feng (31/2 years old) and his big sister Ming (5 years old). Mr. and Mrs. Goh speak both English and Mandarin at home. Feng and Ming, however, prefer to speak English. Concerned about the children's Chinese language development, both Mr. and Mrs. Goh try to use more Mandarin in their daily family talks. Excerpt 3 is a dialogue between Feng and his mother when they were reading a picture book together.

Excerpt 3: Butterfly 叫什么? (October 20, 2009) (Feng: F; Mrs. Goh: M)

$1 \mathrm{~F}$ : Butterfly [points to a picture of a butterfly in the book].

$2 \mathrm{M}$ : What butterfly? Butterfly 叫什么? What butterfly? What is butterfly called? [in Chinese] 


\section{$3 \mathrm{~F}:$ 蝴蝶}

\section{Butterfly [pronounced: hudie]}

$4 \mathrm{M}$ : 好

Good.

It is noticeable in this dialogue that children's "default" language is English, illustrating the effect of the official bilingual policy in recent decades (CurdtChristiansen 2016a, 2016b). Some parents are aware of this slide toward English and have begun to give more explicit attention to children's language behavior. For instance, in Excerpt 3, Feng's mother used a direct request to elicit the Chinese word for "butterfly." In Excerpt 2, we see that parents tend to use more direct and expressed discourse strategies in their attempt to socialize their children into classroom-like practices.

Excerpt 4 provides another example of elicitation. The Teo family has five members, including two grandparents (retired), Mr. Teo (civil servant), Mrs. Teo (school teacher), and Damien (31/2 years old). Mr. and Mrs. Teo speak Mandarin with the grandparents but mostly English to Damien. Damien speaks mostly English to both his grandparents and parents, but Chinese words are occasionally inserted into his utterances.

Excerpt 4: What is lemon called in Chinese? (December 12, 2008)

(Mrs. Teo: M; Damien: D)

$1 \mathrm{M}$ : What is lemon called in Chinese?

2 D: I don't know.

$3 \mathrm{M}$ : What color is lemon?

$4 \mathrm{D}$ : 黄色。 Yellow.

$5 \mathrm{M}$ : lemon is 柠檬 Lemon is ningmeng

6 D: 柠檬.

Ningmeng.

Our observations of family talk reveals that parental discourse strategies tend to follow the widely documented teaching practices of a second-language or foreign-language classrooms in the form of Initiation-Response-Evaluation sequences (Sinclair and Coulthard 1975) as parents often ask direct questions seeking clarifications, requesting comprehension checks or asking for repetitions of vocabulary. In Excerpt 4, the mother asked direct questions in lines 1 and 3, and explicitly taught Damien the word lemon in Chinese in line 5. Although this approach does not match Lanza's parental established 
discourse strategies precisely, it is similar to minimal grasp or expressed guess strategies. In a recent study, Abreu Fernandez (2019) reported similar language practices in Russian-Swedish speaking families in Sweden. Using the term "language workout," she contends that this socialization register provides vocabulary input that helps scaffold children's language use.

Overall, these data suggest that in the Singaporean context parents and grandparents are quite conscious about and explicit in correcting or redirecting children's linguistic behavior, whereas in Lanza's work ([1997] 2004), parents tend to be more implicit or indirect in their socialization practices.

These rather mundane, everyday bilingual conversations illustrate that discourse strategies used by adults have degrees of consciousness and explicitness that vary contextually. In this respect, Singaporean parents/grandparents might intentionally socialize children into separate language use in Malay, English, or Chinese, but the conversations provide limited communicative practice for children to use the languages in a natural manner. Family language policy is thus established over time and based on the interactional styles co-constructed by adults and children. Lanza ([1997] 2004) emphasized that the degrees of implicitness of language socialization in families potentially contribute to the language outcomes.

\section{Identity, Ideology, and Agency in Family Language Policy (Strand Two)}

A second strand of research, evident in more recent work and framed explicitly under the banner of "family language policy" (e.g., Lanza and Curdt-Christiansen 2018; Lanza and Li Wei 2016; Lanza and King 2018; Lanza 2020b; Lanza and Lexander 2019; Lanza and Lomeu Gomes, 2020), includes a detailed analysis of identity, ideology, and agency to better understand home language practices and child language use patterns and development. This line of scholarship is frequently characterized by the use of an anthropological and ethnographic lens and is evident in multiple projects, including bilingual families in the US (King, Fogle, and Logan-Terry 2008), bilingual families in Singapore (CurdtChristiansen 2016a, 2016b), and Korean-English families in the US (Kang 2015), among others. One recent project (Curdt-Christiansen, ongoing) investigates FLP at multiple levels - national, community, and individual families within the UK. At the national level, a survey examines how mobility and the on-going sociopolitical changes influence FLP. At the community level, three communities (Chinese, Polish, and Somali) are studied to make visible the historical trajectories of cultural and linguistic development in relation to migration in diasporic communities. At the individual family level, the project examines how socioeconomic 
pressure, sociopolitical context, public education demands, and linguistic forces, as well as family structure shape the formation of FLP. In what follows, we present a case of one Chinese family from the study, examining their language practices and parental ideology by studying their digital and media practices.

The Liu family moved to England about ten years ago when the parents came to study as international students. They have two girls; the older, Jiejie (15 years old), was born in China and the younger, Meimei (8 years old), in the UK. Learning two languages, English and Chinese, is described by the parents as a smooth and happy journey for Jiejie but less so for Meimei. Before Meimei was born, the family language was predominantly Chinese, and Jiejie reportedly sailed through schools in the UK with excellent academic records. The family language practices continued in Chinese until Meimei was sent to a nursery; it was then that the parents began worrying about Meimei's communication with the adults and children in the nursery. The family language policy changed, as Mrs. Liu explained:

\begin{tabular}{|c|c|}
\hline $\begin{array}{l}\text { 我们非常担心妹妹在幼儿园的交 } \\
\text { 流和沟通问题。特别是老师说 } \\
\text { 妹妹很少说话, 但是她在家里 } \\
\text { 话很多, 不停地说。我们好担 } \\
\text { 心, 这肯定是语言的问题。我 } \\
\text { 们决定多说英语, 后来, 英语 } \\
\text { 越来越多, 那妹妹的中文就不 } \\
\text { 是很理想。她说出来的中文都 } \\
\text { 是外国腔。 }\end{array}$ & $\begin{array}{l}\text { We became very worried about Meimei's } \\
\text { communication skills at the nursery. } \\
\text { Especially when the teacher said that Meimei } \\
\text { hardly spoke at all. But she was very bubbly } \\
\text { at home, always talking non-stop. We } \\
\text { were so concerned. (To us) this was clearly } \\
\text { a language issue. That's why we decided } \\
\text { to change our home language to English. } \\
\text { Then, later on, English was used more and } \\
\text { more; then Meimei's Chinese became less } \\
\text { developed. Now she speaks Chinese like a } \\
\text { foreigner. }\end{array}$ \\
\hline
\end{tabular}

Interview with Mrs. Liu (June 20, 2018)

In this interview, Mrs. Liu recalled and reflected on the critical moment of decision-making when changing her family language policy. Her concerns appear to be widespread, as existing literature suggests that many parents worry about their children's mainstream language development in the host country (Canagarajah 2008; Curdt-Christiansen and LaMorgia 2018; Song 2019). As Spolsky (2012) pointed out, many immigrant parents have to deal with the social realities of public educational demands on the one hand and the desire to maintain family language practices on the other. With this sort of on-going linguistic competition, minority languages are often defeated because they lack public support, educational provisions, and community facilities. In the case of the Liu family, Meimei's Chinese language skills have decreased over the years, as illustrated by the social media communications between her and her family. 
Excerpt 5: Mummy, I miss you (June 8, 2018)

Fri 8 Jun, 16:07

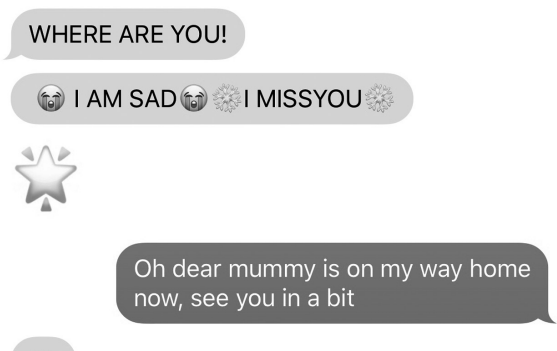

$\mathrm{Ok}$

The social media practices in the family between Meimei and her mother are shown in Excerpt 5, which provides a snapshot of the family's (largely English) language practices. Meimei used capital letters and different emojis when writing to her mum. The texts reflect a typical contemporary social media practice where individuals use multimodality to intensify or lighten up communications that convey their emotions, intentions, frustrations, and appreciations. In the short exchanges, Meimei used (for) (cry face) twice to show how sad she was without her mother.

Excerpt 6: Morning, Meimei (June 19, 2018)

Tue 19 Jun, 08:28

妈

蔵藏 早上好:

Have a nice day love $x x x$

ok

Tue 19 Jun, 21:42

Occasionally, Mrs. Liu also used Chinese in their communications, but the Chinese texts were often immediately followed by English texts, such as the two lines in Excerpt 6. Mum started the conversation by using Chinese to greet Meimei in the morning (when she was away from home), then followed up with the English text: Have a nice day love $x x x$. This communication style was a conscious reflection on the family's language use in recent years, after Mrs. and Mr. Liu had realized that Meimei's Chinese language development had more or less stopped. Although consciously providing opportunities for Meimei to relearn Chinese by sending her to a Chinese school, the communication pattern in the family was difficult to rectify. Mrs. Liu acknowledged that it is difficult for Meimei to communicate with 
the grandparents without the parents' language prompts and support. In the next excerpt, we illustrate a WeChat exchange between Meimei and her grandfather. Meimei recorded her violin rehearsal for grandpa, which she sent together with a voice message asking what grandpa thought about her performance. While the recording was in Chinese, a background coaching from her mother could be clearly heard.

Excerpt 7: Do you love me, grandpa? (January 23, 2019)

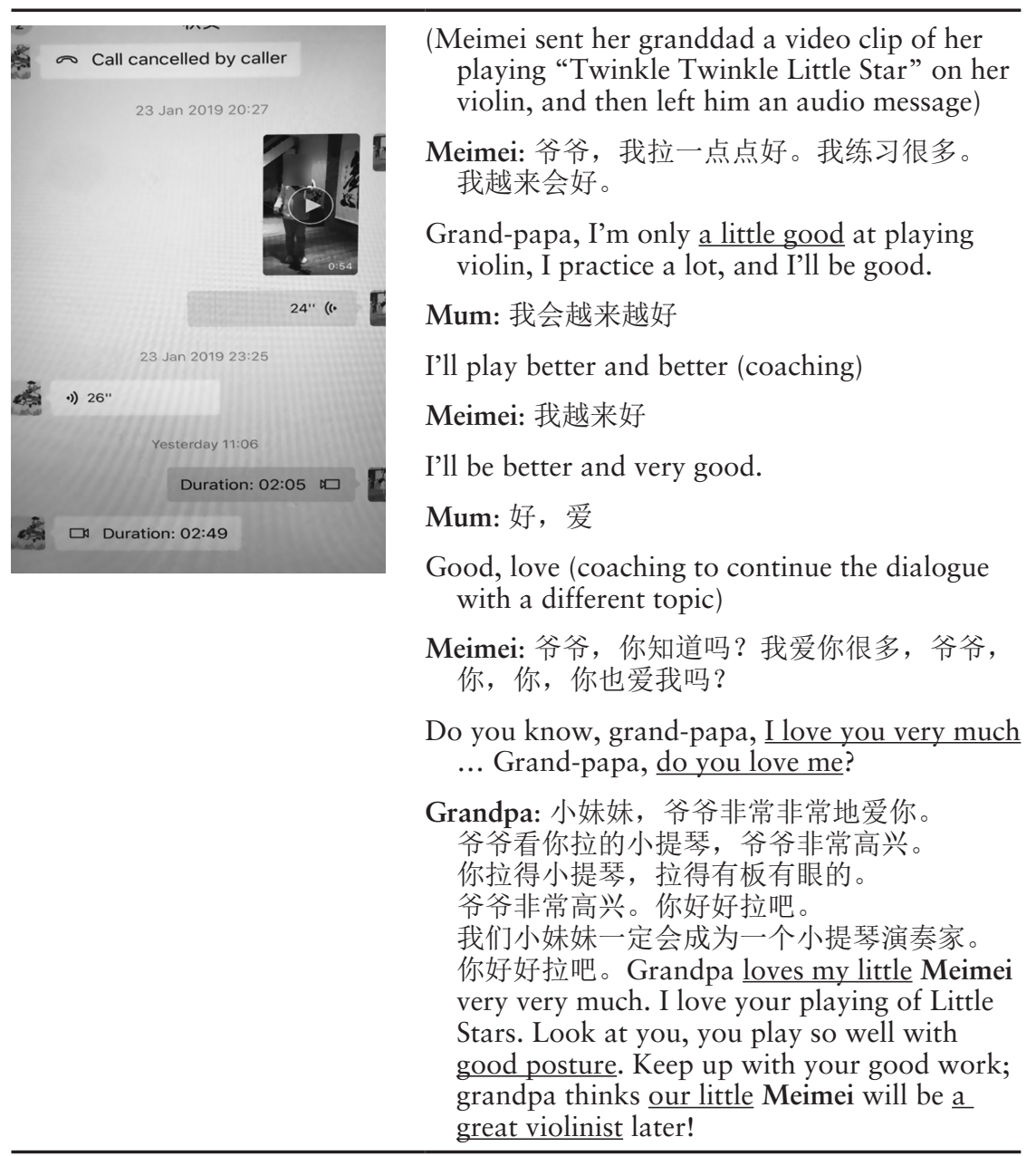

This WeChat exchange illustrated one encounter within a language revitalization initiative in the family. From a heritage language development perspective, this FLP decision can be viewed as a deliberate measure and conscious move to increase Meimei's Chinese language use in real language 
communication. Meanwhile, it is also an opportunity to enforce the emotional ties between Meimei and her grandfather. From an FLP perspective (King, Fogle, and Logan-Terry 2008; King and Fogle 2006), the coaching from the mother goes beyond her parenting intentions as a good mother to include socializing Meimei into using Chinese, demonstrating different functions of Chinese (communication tool with grandparents), and negotiating culturally influenced behaviors and social identities for using expressions. For example, "I am a little good" indicates a modest behavior, "I practice a lot" shows her diligence, and "I love you very much" demonstrates her affection for grandpa. The use of "I" in Meimei's utterances illustrates a strong agency and identity as she "relearns" Chinese and is coached by her mother. The use of "my, our little" from grandpa reinforces their mutual affection, which is further strengthened when grandpa predicts that Meimei will be "a great violinist later."

These data suggest the ways that family language policy in transnational families is context-specific and largely depends on the parents' expectations and aspirations for their children's language and educational development. At the same time, child agency is also evident as a factor influencing family language practices as children negotiate their identity through language use. FLP depends on the sociopolitical environment for supporting bilingual and multilingual development. Very often, parental language aspirations encounter challenges when they collide with societal ideologies that place little value on minority languages. FLP, thus, is not only driven by various language ideologies within families and in society, but it also embodies ideologies in linguistic practices, as evidenced in Meimei's case and in studies by other scholars (Curdt-Christiansen and Lanza 2018; King and Lanza 2018; Lanza and Curdt-Christiansen 2018). FLP has important implications for policymakers at macro (national), meso (educational), and micro (family) levels as it not only concerns explicit and deliberate language planning (King, Fogle, and Logan-Terry 2008) but also meaning-making and language-mediated experiences in families.

\section{Political Dimensions of Family Language Policy (Strand Three)}

A third strand of FLP takes up the political and media dimensions of FLP, including how nationalistic or anti-immigrant discourses impact family language decisions as well as how language decisions and practices within families are in fact political ones. Work in this strand is evident in Lanza and her colleagues' examination of how families and FLP are framed by media and state institutions and how the public is discursively integrated into (or kept out of) the family space.

Exemplary of this work is Purkarthofer, Lanza, and Finstad Berg's (forthcoming) investigation of six years of media coverage and public understandings of Barnevernet, the Norwegian Child Welfare Services Agency. 
Norwegian law strongly favors the rights of the child (relative to those of the family or community), in some instances resulting in the temporary or permanent removal of the child from the family, ostensibly to protect the child from harm. Statistics suggest that immigrant, foreign-born, and minority-language children are disproportionately likely to be removed from their homes by Barnevernet, leading to questions - and public media coverage - concerning the role of the state, the nature of the family, and what constitutes good parenting. Purkarthofer, Lanza, and Finstad Berg (forthcoming) illustrate how media discourses about Barnevernet provide a means to understand multilingual participation in society. In their analysis of media coverage and parent interviews, Purkarthofer, Lanza, and Finstad Berg (forthcoming) find that participants in their study attempt to present their family experiences as "normal." In doing so, they are not only answering to Norwegian expectations about their private spaces but also taking on and reacting to particular public expectations and constructions of family spaces as "good," "appropriate," and ultimately as "safe."

Lanza and her colleagues report that language issues are a major component of the expectations around parenting. In Norway, as in many other countries, politicians actively promote their visions of (more often than not monolingual) societies and parents. Parents in Norway who do not meet these expectations are at risk (or led to believe they are at risk) of losing custody of their children. Their findings have implications for our understanding of how families are defined in Norway and, more broadly, for the study of family language policies in multilingual families (Lanza and Li Wei 2016). The research of Lanza and her colleagues here also points to the importance and value of critical examination of the media - both for what such work can tell us about how "good" or "bad" families are conceived (driven at least in part by the FLPs therein) and the impact of media and social media in shaping FLP. This is an important direction, given the everincreasing access to and influence of all media and the ever-more blurred lines between "mainstream" and "social" media (Shearer and Gottfried 2017). While social media has a profound impact on how we understand and make sense of the world around us more broadly, for parents (and, evidently, mothers in particular) social media have been found to be a powerful source of information and connection and, concomitantly, a source for the understanding of what it means to be a good parent (Duggan et al. 2015).

Perhaps universally, the most basic and crucial component of being a good parent is keeping one's child safe. For many immigrant-background parents in the US, policies and public and media discourses around immigration have direct implications for safety and, indirectly, for family language policy. This is particularly the case for Spanish-speakers, the language spoken by the majority of immigrants in the US (with residents, migrants, and refugees hailing from more than a dozen different Spanish-speaking countries). Despite the long history of Spanish in the US and a large number of speakers (roughly 53 million), Spanish, in many areas of the country, 
is politicized and can be both stigmatized and stigmatizing (Carter 2018; Machado 2019).

The politicization of Spanish intensified under the Trump administration as the deportation of immigrants emerged as a central component of his campaign to "make America great again." In the first eight months of the Trump administration, immigration arrests in the interior of the US, particularly of immigrants without a criminal background, increased by $42 \%$ over the same period the year prior (Lopez, Gonzalez-Barrera, and Krogstad 2018). In subsequent years, deportation numbers have fluctuated (e.g., 288,000 new deportations in the fiscal year ending September 30, 2018) and 143,000 arrests in the 2019 fiscal year, marking the lowest number of arrests to date under the Trump administration. This is a relatively low number of deportations in light of Trump's announcement on Twitter in June 2019 that Immigration and Customs Enforcement (ICE) was preparing to "begin the process of removing the millions of illegal aliens who have illicitly found their way into the United States." While that operation proved largely unsuccessful, these twists and turns in policy and practice have been, to say the least, unnerving for many of the estimated 12 million undocumented individuals who lack legal status (and have no path for attaining it) and currently reside in the US.

Crucial here is the fact that official criteria for questioning, detainment, and potential deportation are largely opaque (Funk 2019). Officially, US ICE is barred from racial profiling and maintains that agents receive training to that effect every six months (Surana 2018). There is, however, ample evidence that race and language in fact render individuals suspect throughout the country. Indeed, US and international media regularly report instances in which individuals were stopped, questioned, and detained by ICE or border officials for speaking a language other than English, most often Spanish. Prominent examples from the last few years include two women (US citizens) who were detained for chatting in Spanish while waiting in a Montana convenience store line (Associated Press 2018). The women have since filed a lawsuit in federal district court to order the US Customs and Border Protection not to stop or detain anyone "on the basis of race, accent and/or speaking Spanish," unless those characteristics are tied to a specific and reliable suspect description (BBC 2018; Wofsy and Borgmann 2019).

Speaking Spanish is routinely portrayed on social media as putting one at risk of being deported, detained, or worse. Spanish-language newspapers regularly run headlines noting, for instance, that "Speaking Spanish in U.S. is a Deportation Risk" (20minutos 2018; La Vanguardia 2018). Widely circulating videos, such as that of a New York City lawyer, Aaron Schlossberg, who denounces restaurant employees for speaking Spanish to each other and shouts that his "next call is to ICE" (BBC 2018; Robbins 2018), effectively create an atmosphere in which Spanish-speakers are positioned as undocumented and at risk of deportation or worse (Carroll 2017). 
Perhaps the most tragic example is that of the Spanish-speakers and immigrant families that were intentionally targeted by the 2019 mass shooter in El Paso, Texas, who killed 22 people and injured 24 others. While this incident was extreme and horrific, it is not unusual in its target: anti-Hispanic incidents have made up around half of all reported ethnic-bias hate crimes since 2004, according to federal data (Fermoso 2018).

Survey data suggest these events and their intense social media coverage affect the lives and experiences of Spanish-speakers in the US. About 40\% of Latinos report feeling discriminated against because of their Latino background (Lopez, Gonzalez-Barrera, and Krogstad 2018). Pew data indicate that the majority of Latinos in the US $(55 \%)$, regardless of legal status, say they worry "a lot" or "some" that they, a family member or a close friend could be deported, up from 47\% who said the same in 2017 (Lopez, Gonzalez-Barrera, and Krogstad 2018). Further, fully two-thirds (66\%) of immigrant Latinos report they worry about deportation, compared with $43 \%$ of those who were born in the US. The share rises to $78 \%$ among those who are likely to be unauthorized (undocumented) immigrants. Language factors come in here as well: Latinos who speak Spanish as their primary language are more likely to worry about deportation than those who speak English as their primary language.

The study of FLP, as Lanza suggests, must take into account these events and their coverage on social media; concomitantly, analysis of social media can help us understand the tensions parents face in establishing their own family language policies. As summarized below, analysis of media geared for Spanish-speaking, immigrant-background families suggests gaps and contradictions with respect to what it means to be a "good parent" (King and Fogle 2006) within a highly politicized context in which Spanish is associated with undocumented legal status (King, in progress).

Analysis of Spanish-language parenting blogs, immigrant support agencies' websites, and social media sites for Spanish-speaking US-based families suggests that safety and preparing for the possibility of detainment and/or deportation are important topics for many Spanish-speaking parents. For instance, many non-profit organizations host sites, materials, and discussion platforms that contain guides, pamphlets, and printable information cards for parents concerned about family separation and potential deportation. These platforms and materials provide tips for talking with children about raids, advice on what to do if ICE comes to the door, and guidance on how to prepare adult and child family members emotionally and logistically for separation. These Spanish-language materials, particularly those published by public service and advocacy organizations, underline the ways in which deportation is a pressing worry and practical concern for many undocumented parents (e.g., Women's Refugee Commission 2019; Southern Poverty Law Center 2020; 20minutos 2018). In these Spanishlanguage materials, Spanish is assumed to be the routine language of communication within the family. 
In contrast, commercially driven social media platforms, blogs, and advice sites targeting Spanish-speaking parents in the US feature a sunnier view of life in the US. These ad-based platforms promote Spanish as a cognitive, academic, social, and occupational advantage for children (e.g., My Latina Table 2020; BabyCenter 2020; Familias 2020). Maintaining and developing Spanish, in these media, is crucial for keeping children connected with their heritage but also for allowing them to cash in on the "bilingual advantage." Such sites, blogs, and discussion forums delve into the "whys" and "hows" of bilingual parenting but make no mention of the political context of Spanish in the US. Many, for instance, assume that international travel is a possible means to promote child language skills and concomitantly ignore the well documented, widely circulating cases of linguistic profiling and anti-Latino discrimination.

In turn, Spanish-language political blogs or opinion pieces frame speaking Spanish publicly as an act of defiance and as a right or even an obligation. These pieces have titles such as "Why we should speak Spanish in public with pride and not be shamed" and exhort readers to do so (Univision 2017). Readers in such pieces are told, for instance, that "[we] should feel proud of our culture and our roots. We cannot have our identity stolen from us, nor speak our mother tongue in hiding" (Barahona 2018). Here, speaking Spanish is positioned as a badge of pride and possibly of courage as well.

In light of the above, for many Spanish-speaking immigrant-background families, and for undocumented parents, in particular, being a "good parent" (King and Fogle 2006) presents some profound dilemmas with respect to language. On the one hand, using Spanish with one's child, particularly in public, carries risks of detainment, harassment, or even violence. On the other hand, Spanish-English bilingualism provides important advantages and raising Spanish-speaking children is both a legal right and a moral obligation; within this discourse, "good parents" work hard to ensure their children develop and maintain their Spanish-language skills. This presents an unrecognized no-win, double-bind for many immigrant-background parents in which there are two idealized (and incompatible) images: the parent who cultivates private and public use of Spanish to give her child a bilingual edge, and the parent who protects her child (and family) from separation, discrimination, and danger. Current research (King, in progress) is examining how parents make sense of this conflict through analysis of parental narratives of language choice.

For researchers of family language policy, analysis of media and parents' understandings of their highly mediated worlds is a significant advance and new direction. With current research suggesting that US adults spend on average 11 hours per day consuming media (Fottrell 2018), the inclusion of this context is increasingly crucial for understanding FLP. In this respect, Lanza and her colleagues' analysis of Barnevernet in Norway was an important insight and advance in the field. 


\section{Conclusion}

This chapter presented three projects in the area of family language policy and highlighted how Elizabeth Lanza's research has been foundational in the development of each. This chapter has underlined the important contributions to the field made by Lanza and her collaborators at the outset and into the present. Her work over the last three decades has advanced our understanding of how languages are learned within families, how families create and define themselves through language, and how the politics of language can challenge families.

Questions of FLP seem all the more crucial in light of the myriad social, economic, and psycho-emotional stressors brought on by the COVID-19 pandemic. Worldwide, quarantines and lockdowns have centralized the family unit but simultaneously put it under huge stress. Concomitantly, technological connections with physically remote family members have become more routine, potentially offering new opportunities to support and grow minoritized languages in the home. Of course, the pandemic has also spotlighted, if not directly exacerbated, existing linguistic, economic, and social inequalities, including uneven access to educational and other state services (e.g., Sugarman and Lazarín 2020). Understanding how - and with what languages and language varieties - families are navigating this new landscape is an important, albeit it technologically and methodologically challenging, new research area in the years ahead.

Lastly, on a personal level, we also wish to recognize and thank Liz for being a supportive and collaborative colleague in our own academic development over the years. Her research has long centered on minority-language communities and the families within them; at the same time, she has built an active, strong, and diverse community of scholars around her as her academic legacy.

\section{Acknowledgment}

Part of the work in this paper is sponsored by the Economic and Social Research Council (ESRC) of Great Britain (ES/N019105/1).

\section{References}

20minutos. May 23, 2018. "Hablar español en Estados Unidos, un deporte de riesgo.” 20minutos. Accessed January 9, 2020. https://www.20minutos.es/notic ia/3347788/0/hablar-espanol-eeuu-riesgo/

Abreu Fernandes, O. 2019. "Language workout in Bilingual Mother-child Interaction: A Case Study of Heritage Language Practices in Russian-Swedish Family Talk." Journal of Pragmatics 140: 88-99.

Associated Press. May 26, 2018. "Why Immigrants in the U.S. Avoid Speaking Their Native Language.” Herald Tribune. Accessed January 10, 2020. https://www.her 
aldtribune.com/zz/news/20180526/why-immigrants-in-us-avoid-speaking-theirnative-language

BabyCenter. 2020. "Estrategias para criar ninos bilingues.” BabyCenter. Accessed January 10, 2020. https://espanol.babycenter.com/a2500013/estrategias-para-cri ar-ni\% C3\%B1os-biling\%C3\%BCes

Barahona, D. May 24, 2018. "Should We be Afraid of Speaking Spanish in Public?" La Noticia. Accessed January 10, 2020. http://www.lanoticia.com/afraid-ofspeaking-spanish-public/

BBC. May 22, 2018. "Why Spanish Speakers in US Are Getting into Trouble." BBC. Accessed January 9, 2020. https://www.bbc.com/news/world-us-canada-44201444

Canagarajah, A.S. 2008. "Language Shift and the Family: Questions from the Sri Lankan Tamil Diaspora.” Journal of Sociolinguistics 12 (2): 143-176.

Carroll, R. March 5, 2017. “America's Millions of Mexicans without Documents Live in Fear of Deportation." The Guardian. Accessed January 10, 2020. https:// www.theguardian.com/us-news/2017/mar/05/deportation-fear-mexicans-los-an geles

Carter, P.M. 2018. "Spanish in US Language Policy and Politics.” In The Routledge Handbook of Spanish as a Heritage Language, edited by K. Potowski, 36-52. New York: Routledge.

Curdt-Christiansen, X.L. 2013a. "Negotiating Family Language Policy: Doing Homework." In Successful Family Language Policy: Parents, Children and Educators in Interaction. Series Multilingual Education 7, edited by M. Schwartz and A. Verschik, 277-295. Dordrecht, Netherlands: Springer. doi:10.1007/978-94-007-7753-8_10.

Curdt-Christiansen, X.L. 2013b. “潜移默化 - Implicit Learning and Imperceptible Influence: Syncretic Literacy of Multilingual Chinese Children." Journal of Early Childhood Literacy 13 (3): 345-367. doi:10.1177/1468798412455819

Curdt-Christiansen, X.L. 2016a. “Conflicting Language Ideologies and Contradictory Language Practices in Singaporean Bilingual Families.” Journal of Multilingual and Multicultural Development 37 (7): 694-709. http://www.tandfonline.com/ doi/full/10.1080/01434632.2015.1127926

Curdt-Christiansen, X.L. 2016b. "Family Language Policy in the Chinese Community in Singapore: A Question of Balance?" In Multilingualism in the Chinese Diaspora Worldwide, edited by Li Wei, 255-275. London and New York: Routledge.

Curdt-Christiansen, X.L. 2020. "Educating Migrant Children in the UK: Language and Educational Practices in Home and School Environments." International Multilingual Research Journal 14 (2): 163-180. doi:10.1080/19313152.2020.1 732524

Curdt-Christiansen, X.L. and F. LaMorgia. 2018. “Managing Heritage Language Development: Opportunities and Challenges for Chinese, Italian and Urdu Speaking Families in the UK." Multilingua: Journal of Cross-Cultural and Interlanguage Communication 37 (2): 177-210. doi: 10.1515/multi-2017-0019

Curdt-Christiansen, X.L. and E. Lanza, eds. 2018. "Special Issue: Language Management in Multilingual Family: Efforts, Measures and Choices." Multilingua: Journal of Cross-Cultural and Interlanguage Communication 37 (2): 123-130. doi:10.1515/multi-2017-0132

Duggan, M., A. Lenhart, C. Lampe, and N.B. Ellison. 2015. "Parents and Social Media.” Pew Research Center. Accessed January 16, 2020. https://www.pew research.org/internet/2015/07/16/parents-and-social-media/ 
Familias. 2020. "Por favor, ¡habla en espanol a tus hijos!” Familias. Accessed January 10, 2020. https://www.familias.com/por-favor-habla-en-espanol-a-tushijos/

Fermoso, J. May 22, 2018. "Why Speaking Spanish is Becoming Dangerous in America." The Guardian. Accessed January 10, 2020. https://www.theguardian. com/us-news/2018/may/22/speaking-spanish-dangerous-america-aaron-schlos sberg-ice

Fottrell, Q. 2018. "People Spend Most of Their Waking Hours Staring at Screens." Accessed January 16, 2020. https://www.marketwatch.com/story/people-arespending-most-of-their-waking-hours-staring-at-screens-2018-08-01

Funk, M. October 2, 2019. "How ICE Picks Its Target in the Surveillance Age." The New York Times. Accessed January 10, 2020. https://www.nytimes.com/2019/1 0/02/magazine/ice-surveillance-deportation.html

Gafaranga, J. 2010. "Medium Request: Talking Language Shift into Being." Language in Society 39 (2): 241-270.

Kang, H. 2015. "Korean Families in America: Their Family Language Policies and Home-language Maintenance.” Bilingual Research Journal 38 (3): 275-291.

King, K.A. and L. Fogle. 2006. "Bilingual Parenting as Good Parenting: Parents' Perspectives on Family Language Policy for Additive Bilingualism." International Journal of Bilingual Education and Bilingualism 9 (6): 695-712.

King, K.A., L. Fogle, and A. Logan-Terry. 2008. "Family Language Policy." Language and Linguistics Compass 2 (5): 907-922.

King, K.A. and E. Lanza, eds. 2018. "Ideology, Agency and Imagination in Multilingual Families: An Introduction.” International Journal of Bilingual Education and Bilingualism 23 (3): 717-723.

King, K.A. and Flugel, S. in press. "Family Language Policy in Social Media: A Double-Bind for "good" Latino Parents."

La Vanguardia. May 23, 2018. "Hablar español es cada vez más peligroso en EE.UU." La Vanguardia. Accessed January 9, 2020. https://www.lavanguardia. com/internacional/20180523/443779277568/hablar-espanol-mas-peligroso-e euu.html

Lanza, E. (1997) 2004. Language Mixing in Infant Bilingualism. Oxford, UK: Oxford University Press.

Lanza, E. 2007. "Multilingualism in the Family." In Handbook of Multilingualism and Multilingual Communication, edited by P. Auer and Li Wei, 45-67. Berlin, Germany: Mouton de Gruyter.

Lanza, E. 2020a. "Urban Multilingualism and Family Language Policy." In Urban Multilingualism in Europe: Bridging the Gap between Language Policies and Language Practices, edited by G. Caliendo, R. Janssens, S. Slembrouck, and P. Van Avermaet, 121-139. Berlin: Mouton de Gruyter.

Lanza, E. 2020b. "Digital Storytelling: Multilingual Parents' Blogs and Vlogs as Narratives of Family Language Policy." In Språkreiser - festskrift til Anne Golden på 70-årsdagen, edited by L.A. Kulbrandstad and G.B. Steien, 177-192. Oslo: Novus Forlag.

Lanza, E. and X.L. Curdt-Christiansen, eds. 2018. "Special issue: Multilingual families: Aspirations and Challenges." International Journal of Multilingualism 15 (3): 231-232. doi: 10.1080/14790718.2018.1477091

Lanza, E. and Li Wei, eds. 2016. "Special Issue: Multilingual Encounters in Transcultural Families." Journal of Multilingual and Multicultural Development 37 (7): 653-654. 
Lanza, E. and K.V. Lexander. 2019. "Family Language Practices in Multilingual Transcultural Families." In Multidisciplinary Perspectives on Multilingualism: The Fundamentals, edited by S. Montanari and S. Quay, 229-252. Berlin, Boston: De Gruyter Mouton.

Lanza, E. and R. Lomeu Gomes. 2020. "Family Language Policy: Foundations, Theoretical Perspectives and Critical Approaches." In Handbook of Home Language Maintenance and Development. Social and Affective Factors, edited by A.C. Schalley and S.A. Eisenchlas, 153-173. Berlin, Boston: De Gruyter Mouton. Lomeu Gomes, R. 2020. “Talking Multilingual Families into Being: Language Practices and Ideologies of a Brazilian-Norwegian Family in Norway." Journal of Multilingual and Multicultural Development. doi:10.1080/01434632.2020.1 788037.

Lopez, M.H., A. Gonzalez-Barrera, J. M. Krogstad. October 25, 2018. "Views of Immigration Policy.” Pew Research Center. Accessed January 9, 2020. https:// www.pewresearch.org/hispanic/2018/10/25/views-of-immigration-policy/

Machado, A. (March 26, 2019). How the U.S Taught Me That Spanish was Shameful. NBC Universal. Accessed January 10, 2020. https://www.nbcnews. com/think/opinion/how-u-s-taught-me-spanish-was-shameful-ncna986746

My Latina Table. 2020. “Consejos para Criar Hijos Bilingües.” My Latina Table. Accessed January 10, 2020. https://www.mylatinatable.com/consejos-para-criarhijos-bilingues/

Purkarthofer, J., E. Lanza, and M. Finstad Berg. (forthcoming). “Transnational Families, the Media and the Norwegian Barnevernet: Discourses between the Public and the Private."

Robbins, L. May 16, 2018. “Man Threatens Spanish-speaking Workers: 'My Next Call Will be to ICE.'” The New York Times. Accessed January 10, 2020. https:// www.nytimes.com/2018/05/16/nyregion/man-threatens-spanish-language-video .html

Shearer, E. and J. Gottfried. September 7, 2017. "News Use Across Social Media Platforms 2017." Pew Research Center. Accessed January 9, 2020. https://www. journalism.org/2017/09/07/news-use-across-social-media-platforms-2017/

Sinclair, J. and M. Coulthard. 1975.Toward an Analysis of Discourse: The English Used by Teachers and Pupils. Oxford: Oxford University Press.

Song, K. 2019. “Immigrant Parents' Ideological Positioning on Bilingualism.” Theory into Practice 58 (3): 254-262.

Smith-Christmas, C. 2016. Family Language Policy: Maintaining an Endangered Language in the Home. Basingstoke: Palgrave Macmillan.

Smith-Christmas, C. 2018. “'One Cas, Two Cas:' Exploring the Affective Dimensions of Family Language Policy.” Multilingua: Journal of Cross-Cultural and Interlanguage Communication 37 (2): 211-230.

Southern Poverty Law Center. 2020. "Issues: Immigrant Justice.” Southern Poverty Law Center. Accessed January 9, 2020. https://www.splcenter.org/issues/im migrant-justice

Spolsky, B. 2012. "Family Language Policy - The Critical Domain." Journal of Multilingual and Multicultural Development 33 (1): 3-11.

Sugarman, J. and M. Lazarín. 2020. Educating English Learners during the COVID19 Pandemic: Policy Ideas for States and School Districts. Washington, DC: Migration Policy Institute. 
Surana, K. June 8, 2018. "How Racial Profiling goes Unchecked in Immigration Enforcement.” Pro Publica. Accessed January 19, 2020. https://www.propublica. org/article/racial-profiling-ice-immigration-enforcement-pennsylvania

Trump, D.J. June 17, 2019. “Next week ICE....” Accessed September 26, 2020. https://twitter.com/realdonaldtrump/status/1140791400658870274?lang=en

Univision. June 6, 2017. "Por qué debemos hablar español en público y con orgullo y no dejar que nadie nos silencie." Univision Noticias. Accessed January 16, 2020. https://www.univision.com/noticias/inmigracion/por-que-debemos-hablar-espan ol-en-publico-y-con-orgullo-y-no-dejar-que-nadie-nos-silencie.

Wofsy, C. and C. Borgmann. February 14, 2019. "U.S Border Patrol Detained U.S Citizens for Speaking Spanish in Montana.” ACLU. Accessed January 10, 2020. https://www.aclu.org/blog/immigrants-rights/ice-and-border-patrol-abuses/usborder-patrol-detained-us-citizens-speaking

Women's Refugee Commission. June 19, 2019. "Migrant Rights And Justice: Resources for Families Facing Deportation and Separation." Women's Refugee Commission. Accessed January 9, 2020. https://www.womensrefugeecommission. org/rights/resources/1409-resources-for-families-facing-deportation-separation 